\title{
Debt: The Good. The Bad. The Ugly
}

\author{
Emine Boz ${ }^{1} \cdot$ Linda Tesar $^{2}$
}

๑ International Monetary Fund 2021

JEL Classification E0 $\cdot$ F0

At the time of the 20th Jacques Polak Annual Research Conference in November 2019, global debt stood at over 230 percent. Since then, that figure has ballooned to over 360 percent of world GDP, largely due to the COVID-19 pandemic and the fiscal measures taken to support economic activity around the globe. Not all debt is the same, of course, nor is it evenly distributed across countries, regions or sectors. Debt can facilitate the expansion of productive investment, including the funds to repair and expand infrastructure necessary for continued economic growth. At the same time, debt overhang and increased debt service can leave economies vulnerable to rollover risk, sudden tightening of credit and even default. Given the prominence of higher debt across advanced, emerging, frontier markets as well as in low-income countries - even before the pandemic - the conference focused on "Debt: The Good. The Bad. The Ugly" and brought together researchers and policymakers to discuss innovative research in this area and facilitate the exchange of views. This issue of the IMF Economic Review features a selection of the papers presented at the conference.

The first article in this issue is the Mundell-Fleming Lecture, "Can Policy Tame the Credit Cycle," given by Jeremy Stein (Harvard University). Stein begins his lecture by emphasizing two sets of stylized facts on the relationship between credit growth and the macroeconomy. At relatively low frequencies, rapid credit growth tends to foreshadow adverse macroeconomic outcomes. He also finds that elevated credit-market sentiment - as measured by a low cost of bearing risk-conveys negative information about future economic growth, above and beyond that impounded in credit-quantity variables. Stein divides theoretical work on the real effects of credit conditions into two categories: those based on financial frictions and those that feature an independent role for investor beliefs, or sentiment. He argues that the rational theories of credit booms based on externalities due to leverage immediately suggest a role for constraints on leverage. Thus, these models provide a basis for some of the most familiar forms of regulatory intervention that we observe, such as

Emine Boz

EBoz@imf.org

1 Washington, D.C, USA

2 University of Michigan, Ann Arbor, MI, USA 
time-invariant bank capital requirements. By contrast, sentiment-based theories suggest that there is time variation in credit-market conditions, and that more activist policies may be necessary to lean against an incipient credit boom. The challenge facing policymakers is knowing which policy is the right one for taming the credit cycle.

In "Credit Disintermediation and Monetary Policy," Nicolas Crouzet (Northwestern University) documents that the share of loans in total debt of US firms appears to have declined since the early 1990s. The paper explores the implications of this "disintermediation" trend for the transmission of monetary policy shocks. The results suggest that empirically, investment among firms with high loan shares is significantly more responsive to monetary policy shocks. Moreover, this passthrough has declined since the early 1990s, when disintermediation started. A model where firms choose debt structure by trading off the flexibility of loans against the lower cost of bonds can account for the higher sensitivity of more bank-dependent firms to monetary shocks. In this model, disintermediation also leads to a decline in the overall pass-through of monetary shocks to investment.

"Exchange Rate Fluctuations and Firm Leverage" by Sebnem Kalemli-Ozcan (IMF, University of Maryland, NBER, CEPR), Xiaoxi Liu (Bank for International Settlements) and Ilhyock Shim (Bank for International Settlements) turns to international evidence on the effect of exchange rate fluctuations on firm leverage. Using firm-level data for leverage in 10 emerging market economies during the period from 2002 to 2015, the paper shows that firms operating in countries whose nonfinancial sectors hold more of the debt in foreign currency increase (decrease) their leverage relatively more after home currency appreciations (depreciations). Combining the leverage data with firm-level information on the currency denomination of debt in four emerging markets, the paper confirms its findings at the most granular level. The quantitative results are asymmetric: The effects of depreciations on firms' leverage and net worth, generally associated with capital outflows and sudden stops, are quantitatively larger than those of appreciations, which typically coincide with capital inflows and at a slower pace. Considering depreciations and appreciations of similar size, the results suggest that the negative impact due to binding financial frictions during depreciations will be larger than the positive impact due to a relaxation of such frictions during appreciations.

"On Public Spending and Economic Unions" by Fernando Broner (CREI, UPF, and Barcelona GSE), Alberto Martin (European Central Bank, CREI, UPF, and Barcelona GSE), and Jaume Ventura (CREI, UPF, and Barcelona GSE) analyzes the conduct of fiscal policy in a financially integrated union in the presence of financial frictions. Frictions create a wedge between the return to investment and the unionwide interest rate. This leads to an overspending externality. While the social cost of spending is the return to investment, governments care mostly about the (depressed) interest rate they face. In other words, the crowding out effects of public spending are partly "exported" to the rest of the union. The paper argues that it may be hard for the union to deal with this externality through the design of fiscal rules, which are bound to be shaped by the preferences of the median country and not by efficiency considerations. The paper also analyzes how this overspending externality — and the union's ability to deal with it—changes when the union is financially

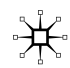


integrated with the rest of the world. Finally, extending the model by introducing a zero lower bound on interest rates, the paper shows that if financial frictions are severe enough, the union is pushed into a liquidity trap and the direction of the spending externality is reversed. At such times, fiscal rules that are appropriate during normal times might backfire.

"Restructuring Sovereign Bonds: Holdouts, Haircuts and the Effectiveness of CACs" by Chuck Fang (The Wharton School), Julian Schumacher (European Central Bank) and Christoph Trebesch (Kiel Institute, Kiel University, CEPR) studies the role of collective action clauses (CACs) in resolving sovereign debt crises. CACs can help avoid the "holdout problem," the risk that creditors refuse to participate in a debt restructuring. Results based on a comprehensive new dataset of 23 bond restructurings with external creditors since 1994 indicate that there is a large variation in holdout rates across types of loans and across countries. In a restructuring, bonds with higher haircuts tend to have higher holdout rates, and the same is true for small bonds and those issued under foreign law. CACs can be effective in reducing holdout risks, but classic CACs, with bond-by-bond voting, are not sufficient to assure high participation rates. Simulations suggest that only the strongest form of CACs, with single-limb aggregate voting, minimizes the holdout problem. The results help to inform theory as well as current policy initiatives on reforming sovereign bond markets.

"r - g < 0: Can We Sleep More Soundly?" by Paolo Mauro and Jing Zhou (both IMF) argues that, contrary to the traditional assumption of interest rates on government debt exceeding economic growth, negative interest-growth differentials became prevalent after the global financial crisis and before the COVID-19 pandemic. The paper then asks whether negative differentials are reassuring, despite the high level of government debt. Based on interest-growth differentials for 55 countries over a long sample (in some countries back two hundred years), the study finds that negative differentials are not new and have prevailed in both advanced and emerging economies. Even so, several default episodes have followed periods of negative differentials, and differentials are no higher prior to defaults than in normal times. Marginal (rather than average) government borrowing costs often rise sharply, but just preceding default. Based on these results, the paper's answer is that our sleep should be troubled, given current conditions.

"The Relationship between Debt and Output" by Yun Jung Kim (Sogang University) and Jing Zhang (Federal Reserve Bank of Chicago) investigates the dynamic relationship between debt and output in a panel of 72 countries over the period 1970-2014 using a vector autoregression (VAR). The paper starts with the predictions of the standard small open economy of Aguiar and Gopinath (2007), where debt and output endogenously respond to total factor productivity (TFP) shocks. The model predicts that because TFP shocks have a large permanent component, debt tends to rise after a positive shock to output. Second, following a shock that increases debt, the model predicts an increase in output. Both of these predictions are contradicted by data_-debt tends to fall after a shock to output, and output tends to fall after a shock to debt. The authors conclude that the relationship between debt and output depends on the sector taking on debt (households, firms or governments) and the source of financing (domestic versus external). The relationship between 
debt and output is also sensitive to the degree of economic development and the exchange rate regimes.

This issue includes a Policy Corner article based on a discussion between Olivier Blanchard (Peterson Institute) and Kenneth Rogoff (Harvard University), moderated by Gita Gopinath (IMF). The topic of their wide-ranging conversation was "Public Debt and Fiscal Policy" and is presented in this issue as a transcript of their remarks. Hopefully, this format captures the energy of the back-and-forth between the two former IMF chief economists as they debate the central questions facing policymakers with respect to debt: how much debt is too much debt, how best to structure debt, how should governments time their borrowing and their repayment efforts and what factors should one consider in evaluating the riskiness of debt.

Even though the conference was held prior to the outbreak of the COVID-19 pandemic, the lessons are relevant for the post-COVID-19 world as countries either struggle to meet their existing debt obligations or increase their debt at a fast pace to overcome pandemic-related challenges. We thank all the authors for their valuable contributions to this issue and hope that you will enjoy reading it.

Publisher's Note Springer Nature remains neutral with regard to jurisdictional claims in published maps and institutional affiliations.

Emine Boz is an Assistant to the Director at the Research Department of the IMF and a Co-Editor of the IMF Economic Review. She holds a Ph.D. from the University of Maryland and has been at the IMF since 2006. Her work has mainly focused on international macro and trade. She has published in several leading academic journals including the American Economic Review, Journal of Monetary Economics and the Journal of International Economies.

Linda Tesar is a Professor of Economics in the Department of Economics at the University of Michigan. She served as Department Chair from 2007 to 2011. Professor Tesar is a Research Associate at the National Bureau of Economic Research and has been a visitor in the Research Departments of the International Monetary Fund, the Board of Governors, and the Federal Reserve Bank in Minneapolis. During 2014-15, Professor Tesar served as a Senior Economist on the Council of Economic Advisers. She is currently the Editor of the IMF Economic Review and a member of the Advisory Board of the Carnegie-NYU-Rochester Conference on Public Policy. Professor Tesar's research focuses on issues in international finance, with particular interests in the international transmission of business cycles and fiscal policy, the benefits of global risksharing, global capital flows, the impact of exchange rate exposure, international tax competition and the European crisis. 